\title{
Kleptoparasitism of harvester ants by the giant kangaroo rat (Dipodomys ingens) in the Carrizo Plain, California
}

\author{
Matthew Polvorosa Kline ${ }^{1}$, Jeff A. Alvarez ${ }^{2, *}$, and Nicole Parizeau ${ }^{3}$ \\ ${ }^{1}$ Lagunitas, CA 94938 \\ ${ }^{2}$ The Wildlife Project, Box 188888, Sacramento, CA 95818

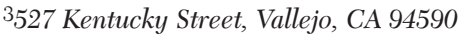

\begin{abstract}
Kangaroo rats are reported to have a mutualistic relationship with harvester ants through facilitation of burrow establishment, creation, and persistence. The relationship can, however, become more complex. We report observations of the giant kangaroo rat (Dipodomys ingens), a state and federally listed endangered species, repeatedly kleptoparasitizing harvester ants from a nearby nest in the Carrizo Plain, California. Though the relationship between kangaroo rats and harvester ants has been studied extensively and is believed to be mutualistic, under certain conditions this relationship can follow an alternate path of parasitism.
\end{abstract}

RESUMEN.-Se ha reportado que las ratas canguro mantienen una relación mutualista con las hormigas cosechadoras mediante la facilitación del establecimiento, creación y persistencia de madrigueras. Sin embargo, la relación puede volverse más compleja. En este estudio, presentamos observaciones de la rata canguro gigante (Dipodomys ingens; una especie que se encuentra en la lista estatal y federal de especies en peligro de extinción) en donde en repetidas ocasiones cleptoparasita a las hormigas cosechadoras de un nido cercano en la Llanura Carrizo, California. Aunque, se ha estudiado extensamente la relación entre las ratas canguro y las hormigas cosechadoras, considerándola como una relación mutualista, bajo ciertas condiciones esta relación puede seguir un camino alternativo de parasitismo.

Symbiotic relationships occur with great regularity between and within plant and wildlife species (Diamond and Case 1986, Douglas 1994). These relationships can be straightforward (e.g., between internal parasites and their hosts) or complex (e.g., ecological relationships that change with environmental factors such as season, behavior, or resources), and can be characterized as mutualistic, parasitic, or both. An example of a symbiosis that transforms is the relationship between butterflies and the flowering plants they visit. Specifically, the relationship between a monarch butterfly (Danaus plexippus) and a milkweed plant (Asclepias spp.) can be parasitic during the butterfly's larval phase but mutualistic during its adult phase. Ecological relationships can also transform when 2 species compete during one life stage or season but have a mutualistic relationship at another. This is observed between some fish species, for example, when a small "cleaner" fish (e.g., Bodianus spp. or Cirrhilabrus spp. [wrasse]) competes with the larvae of large predatory fishes (e.g., Epinephelus spp. and Mycteroperca spp. [grouper]) but develops a mutualistic relationship as the latter species approaches or reaches its adult life stage.

Kleptoparasitism is a refined form of parasitism in which the parasite steals resources from conspecifics or other species. This behavior has been witnessed within and between many wildlife groups, including insects (e.g., ants [Formicidae]), many fishes (Teleostei), crocodilians (Alligatoridae), raptors (Falconidae and Accipitridae), squirrels (Sciuridae), carnivorous mammals (e.g., hyena [Hyaenidae]), and others (Heredia and Clark 1984, Watt et al. 1995, Jorde and Lingle 1988, Brown et al. 2003, Iyenger 2008).

A mutualistic relationship between Dipodomys spp. (kangaroo rats) and ants (Pheidole spp., Pogonomyrmex spp. [harvester ants], Aphaenogaster spp., and others) has been reported or suggested by many researchers (Mares and Rosenzweig 1978,

*Corresponding author: jeff@thewildlifeproject.com 
Davidson et al. 1984, 1985, Schooley et al. 2000). Observations reported here, however, suggest that Dipodomys ingens (giant kangaroo rat) is a facultative kleptoparasite of Pheidole spp. in the Carrizo Plain, San Luis Obispo County, California. Furthermore, we report here on a potential transformation of the ecological relationships-mutualistic and kleptoparasitic-between the giant kangaroo rat and Pheidole spp.

The Carrizo Plain National Monument (Carrizo Plain) is a semiarid grassland dominated by European annual grasses such as red brome (Bromus madritensis rubens), barley (Hordeum murinum), and red-stemmed filaree (Erodium cicutarium). It receives approximately $23 \mathrm{~cm}$ of rain annually, which typically falls during the winter months; the site is essentially dry during the summer. The plain supports numerous declining, threatened, and endangered species of plants, invertebrates, and vertebrates (Williams et al. 1998).

During detailed observational monitoring of a population of Vulpes macrotis mutica (San Joaquin kit fox) within the boundaries of the Carrizo Plain in summer 2013, we also closely observed other species in the area. Among these was the giant kangaroo rat, listed as endangered by the U.S. Fish and Wildlife Service and the California Department of Fish and Wildlife. The species has a very restricted range, and populations are generally legally protected from the direct impacts of anthropogenic activity (Williams et al. 1998, Ried 2006). Because additions to the understanding of this declining species may assist in its recovery, we collected observational data on the giant kangaroo rat coincidentally with those for the San Joaquin kit fox.

On 3 occasions over 3 separate evenings, an individual giant kangaroo rat was observed leaving its burrow around sunset. Approximately $7 \mathrm{~m}$ from the kangaroo rat's own burrow hole was the nest of a harvester ant colony. On each of the 3 evenings, columns of ants worked around multiple entrances to their subterranean colony, the majority carrying various seeds and plant parts. Each time the kangaroo rat left its burrow, it moved directly toward an ant column at one of the colony entrances and immediately dragged its forelimbs through the ants. As it did this, it collected seeds dropped by the disturbed ants and sequestered the seeds in its cheek pouches. At the same time, ants that were not carrying seeds, or had dropped them, swarmed the mammal's hind legs and lower body. The kangaroo rat began kicking, presumably to fend off the attack, but continued to collect seeds. After several minutes, and with cheek pouches clearly distended, the giant kangaroo rat either returned to its burrow or moved down the column of ants to pilfer seeds elsewhere in the line.

Kangaroo rats reportedly use their forelimbs to distinguish food items from nonfood items (Lawhon and Hafner 1981). From our observations of a giant kangaroo rat using its forelimbs to harass worker harvester ants into dropping their seeds, the action appeared to be focused and purposeful-intentional kleptoparasitism. The kangaroo rat appeared to devote itself to foraging kleptoparasitically from the ants. Although the individual was never observed foraging in the absence of the Pheidole sp. over the 3 - $\mathrm{d}$ period-which suggests that it deliberately exploited the ants' presence-we speculate that, overall, this kleptoparasitic relationship is facultative. We feel that our speculation is supported by field observations in the Carrizo Plain that suggest a general paucity of Pheidole spp. but a relative abundance of giant kangaroo rats in the area (Prugh and Brashares 2010).

In the instance of this observation, the kangaroo rat burrow and the nest entrances of the harvester ant colony were in the same vicinity, 7 to $8 \mathrm{~m}$ apart. It is not known whether the proximity of the 2 species' dwellings was coincidental or reflects a pattern of behavior, but clearly the commensalistic advantage to the kangaroo rat of such a proximal abundance of resources would be substantial, saving energy and decreasing the risk of predation (Thompson 1986, Bowers 1990, Hamilton 2002, Flower et al. 2013). We did note that a congener, D. heermanni (Heermann's kangaroo rat), was reported as kleptoparasitizing Veromessor pergandei (black harvester ant) with comparable effect: "One student noted that it gleaned seeds from the entrance to dens." (Jameson and Peeters 1988).

The ants in our observations appeared to receive no benefit from this kleptoparasitic relationship; they lost palpable resources and expended valuable energy collecting the seeds. It has been suggested by Prugh and Brashares (2012), however, that ants, among 
other species, may be provided food subsidies by giant kangaroo rats, which store seeds underground and at surface caches. In other words, the potential cost of kleptoparasitism of the harvester ant's resources may transform seasonally to a net benefit. Certainly the kangaroo rat's behavior does not appear to have altered this ant colony's site selection. Furthermore, Prugh and Brashares (2012) suggest that giant kangaroo rats have no effect on ant abundance within the Carrizo Plain, and Edelman (2012) has reported that kangaroo rats actually facilitate existence for some ant species through soil disturbance and selective seed predation. If this is the case, constructing ant colony sites close to the burrows of the giant kangaroo rat may outweigh the relatively small volume of lost resources. This might indicate that kleptoparasitism by the kangaroo rat is in fact part of a more complex transforming ecological relationship between the 2 species-a relationship both parasitic and mutualistic, which may change seasonally.

The observations reported here occurred over only a few days and may not reflect a common behavior over a wide area. This suggests that some giant kangaroo rats would kleptoparasitize when conditions suit their needs. It is known that harvester ants typically select smaller seeds than those preferred by kangaroo rats when the latter forage directly (Samson et al. 1992), so kleptoparasitism of harvester ant resources may occur when the resources of giant kangaroo rats diminish due to seasonal or environmental stressors.

If there is significant dependency, or a more complex interdependency, between the giant kangaroo rat and ant foraging activity, protection of one species may be closely tied to the other. Additional research into the relationship between these species should be considered. Until further research can be conducted, we suggest that researchers and land managers consider this relationship when conducting landscape alterations, pest control activities, and other actions that may affect one or both species.

\section{ACKNOWLEDGMENTS}

We are grateful to 2 anonymous reviewers whose insight and suggestions for changes to this manuscript improved it greatly. We also thank the Bureau of Land Management for access to the study site.

\section{Literature Cited}

Bowers, M.A. 1990. Exploitation of seed aggregates by Merriam's kangaroo rat: harvesting rates and predatory risk. Ecology 71:2334-2344.

Brown, J.L., A.B. Montoya, E.J. Gott, and M. Curti. 2003. Piracy as an important foraging method of Aplomado Falcons in southern Texas and northern Mexico. Wilson Bulletin 115:357-359.

Davidson, D.W., R.S. InOuYe, and J.H. Brown. 1984. Granivory in a desert ecosystem: experimental evidence for indirect facilitation of ants by rodents. Ecology 65:1780-1786.

Davidson, D.W., D.A. Samson, and R.S. Inouye. 1985. Granivory in the Chihuahuan Desert: interactions within and between trophic levels. Ecology 66: 486-502.

Diamond, J.M., AND T.J. Case. 1986. Community ecology. Harper Collins Publishing, New York, NY.

DougLas, A.E. 1994. Symbiotic interactions. Oxford University Press, New York, NY.

Edelman, A.J. 2012. Positive interactions between desert granivores: localized facilitation of harvester ants by kangaroo rats. PLOS ONE 7:e30914.

Flower, T.P., M.F. Child, and A.R. Ridley. 2013. The ecological economics of kleptoparasitism: pay-offs from self-foraging versus kleptoparasitism. Journal of Animal Ecology 82:245-255.

Hamilton, I.M. 2002. Kleptoparasitism and the distribution of unequal competitors. Behavioral Ecology $13: 260-267$.

Heredia, B., and W.S. Clark. 1984. Kleptoparasitism by White-tailed Hawk (Buteo albicaudatus) on Blackshouldered Kite (Elanus caeruleus leucurus) in southern Texas. Journal of Raptor Research 18: $30-31$.

IYENGAR, E.V. 2008. Kleptoparasitic interactions throughout the animal kingdom and a re-evaluation, based on participant mobility, of the conditions promoting the evolution of kleptoparasitism. Biological Journal of the Linnean Society, 93:745-762.

Jameson, E.W., JR., and H. Peeters. 1988. California mammals. University of California Press, Berkeley, CA.

Jorde, D.G., AND G.R. LingLe. 1988. Kleptoparasitism by Bald Eagles wintering in south-central Nebraska. Journal of Field Ornithology 1988:183-188.

LAWHON, D.K., AND M.S. HaFNER. 1981. Tactile discrimination ability and foraging strategies in kangaroo rats and pocket mice (Rodentia: Heteromyidae). Oecolgia 50:303-309.

Mares, M.A., AND M.L. Rosenzweig. 1978. Granivory in North and South American deserts: rodents, birds, and ants. Ecology 59:235-241.

Prugh, L.R., and J.S. Brashares. 2010. Basking in the moonlight? Illumination increases the capture success of the endangered giant kangaroo rat. Journal of Mammalogy 91:1205-1212.

Prugh, L.R., and J.S. Brashares. 2012. Partitioning the effects of an ecosystem engineer: kangaroo rats control community structure via multiple pathways. Journal of Animal Ecology 81:667-678. 
RIED, F.A. 2006. A field guide to the mammals of North America. Houghton Mifflin Company, New York, NY.

Samson, D.A., T.E. Phillipi, AND D.W. Davidson. 1992. Granivory and competition as determinants of annual plant diversity in the Chihuahuan Desert. Oikos 65:61-80.

Schooley, R.L., B.T. Bestelmeyer, AND J.F. Kelly. 2000. Influence of small-scale disturbances by kangaroo rats on Chihuahuan Desert ants. Oecologia 125: $142-149$.

Thompson, D.B.A. 1986. The economics of kleptoparasitism: optimal foraging, host and prey selection by gulls. Animal Behaviour 34:1189-1205.
WatT, J., B. Krausse, and T.M. Tinker. 1995. Bald Eagles kleptoparasitizing sea otters at Amchitka Island, Alaska. Condor 97:588-590.

Williams, D.F., E.A. Cypher, P.A. Kelly, K.J. Miller, N. Norvell, S.E. Phillips, C.D. Johnson, And G.W. Colliver. 1998. Recovery plan for upland species of the San Joaquin Valley, California. U.S. Fish and Wildlife Service, Portland, OR.

Received 26 October 2017 Revised 16 April 2018 Accepted 30 April 2018 Published online 10 July 2018 